\title{
Characterising the response of vegetation cover to water limitation in Africa using geostationary satellites
}

\author{
Çağlar Küçük ${ }^{1,2}$, Sujan Koirala ${ }^{1}$, Nuno Carvalhais ${ }^{1,3}$, Diego G. Miralles ${ }^{2}$, \\ Markus Reichstein ${ }^{1}$, Martin Jung ${ }^{1}$ \\ ${ }^{1}$ Department of Biogeochemical Integration, Max Planck Institute for Biogeochemistry, Jena, Germany \\ ${ }^{2}$ Hydro-Climate Extremes Lab (H-CEL), Faculty of Bioscience Engineering, Ghent University, Ghent, \\ Belgium \\ ${ }^{3}$ CENSE, Departamento de Ciências e Engenharia do Ambiente, Faculdade de Ciências e Tecnologia, \\ Universidade NOVA de Lisboa, Caparica, Portugal
}

\section{Key Points:}

- We detect seasonal decay periods of fractional vegetation cover at Africa from daily geostationary satellite time series at $5 \mathrm{~km}$ resolution

- We provide observation-based metrics characterising dynamics of decay periods to improve our understanding in vegetation-water interactions

- The metrics contain valuable information on underlying processes of decay related to water limitation like plant accessible water storage

Corresponding author: Çağlar Küçük, ckucuk@bgc-jena.mpg.de 

in African drylands has been shown in various studies (Sankaran et al., 2005, 2008; Merbold et al., 2009; F. Wei et al., 2019). Moreover, evidence suggests that ecosystem functioning - even in the wettest part of the continent, the central African tropical forest responds to soil moisture fluctuations (Guan et al., 2013; Gond et al., 2013) along with co-limitations of other factors such as radiation (Adole et al., 2019). Within the complex rainfall seasonality patterns having unimodal, bimodal or trimodal regimes, less than $5 \%$ of the continent is reported to be non-seasonally humid (Herrmann \& Mohr, 2011).

Soil moisture is the critical variable that characterises the water limitation of vegetation (Porporato et al., 2001), which, in turn, shapes land-atmosphere exchanges of carbon, water, and energy fluxes (Gentine et al., 2012), phenology (Peñuelas et al., 2004), and vegetation functional traits (Guan et al., 2015; W. Zhang et al., 2019), along with their species or biome distribution (Xu et al., 2016). Rainfall is the primary source of moisture but plant available water in drylands is characterised by non-trivial and complex ecohydrological processes that control the availability of moisture from secondary sources (D'Odorico et al., 2019). In fact, Wilcox et al. (2017) conceptualised three critical ecohydrological junctures: (1) infiltration versus overland flow, (2) soil evaporation versus transpiration, and (3) root water uptake versus drainage, that are all centred around the hydrological response of the ecosystem.

Beyond precipitation intensity, topography, and soil properties, the first juncture is affected by presence of vegetation patches that interact with overland flow causing the typical runoff-runon dynamics at hillslope-scale (Ludwig et al., 2005). The second juncture, partitioning of terrestrial evaporation, is critical as an interplay between biological activity and productivity, and physical water losses by direct evaporation. Vegetation transpiration generally dominates terrestrial evaporation (Z. Wei et al., 2017), and the partitioning is controlled more by vegetation and soil characteristics given the climate (Nelson et al., 2020), highlighting a pivotal role of vegetation. The third juncture within the root zone is largely controlled by below-ground vegetation properties, such as depth and distribution of roots, that control the soil-plant hydraulics continuum. Deep rooting facilitates access to a larger moisture reservoir, a frequently observed trait in savanna and woodland ecosystems (Kleidon \& Heimann, 1998; Guswa, 2008). In fact, the diversity and complementarity of ecohydrological plant traits by different species within ecosystems was shown to determine resilience to drought (Anderegg et al., 2018) and to maximise plant water use (Scanlon et al., 2005; Caylor et al., 2009).

There are further ecohydrological phenomena that should be considered when exploring vegetation-water interactions, emerging from non-monotonic ecosystem responses to episodic events, and ephemeral waterbodies occurring across spatial scales. Non-monotonic effects of soil properties on the interaction between climatological aridity and vegetation can lead to the frequently observed "inverse texture effect" in arid climates, whereby sandy soils appear to be associated with less water stress compared to clay soils, due to their higher infiltration capacity (Noy-Meir, 1973). Additionally, dryland ecosystems locally return nearly all rainfall back to atmosphere as terrestrial evaporation (Newman et al., 2006) with very little water draining from the root zone to groundwater (Wilcox et al., 2017), except extreme rainfall events that episodically recharge aquifers (Taylor et al., 2013; J. Zhang et al., 2016). Moreover, riparian processes such as river channel losses from ephemeral rivers can provide critical source of moisture (Tooth, 2000; Mansell \& Hussey, 2005; Jacobson \& Jacobson, 2013; Wang et al., 2018). Riparian corridors and groundwater-fed valleys, therefore, often appear as "green islands" (Eamus et al., 2015), where access to the shallow groundwater supports vegetation activities. In such ecosystems, the growing season may continue several months after the rain season has ceased while the trees appear to have access to groundwater via deep roots or recharge their trunks with water during these times (Guan, Wood, et al., 2014; F. Tian et al., 2018).

Previous studies, therefore, provide clear evidence that vegetation functions are controlled by moisture availability in non-humid climate, with moisture availability, itself, 




Since canopy height is an important indicator of ecosystem functions and is associated mostly with water limitation (Tao et al., 2016), we analysed the effects of canopy height on the decay rate of vegetation cover through their covariation in space. We used the lidar-derived canopy height data from the retrievals of the ICEsat satellite at a spatial resolution of $1 \mathrm{~km}$ (Simard et al., 2011). We used the data after aggregating (simple average) to $0.0417^{\circ}$.

\section{Tree Cover}

We used tree cover data in order to analyse the sensitivity between the relationship of decay rate of FVC and climatological aridity. We used the tree percent component of the MOD44B Version 6 Vegetation Continuous Fields from MODIS (Dimiceli et al., 2015), which is available globally in 250 meter spatial and annual temporal resolution. We aggregated the product in space to the target resolution of this study by taking the mean of higher resolution grid cells. Finally, we used the median tree cover value over the years covering the temporal domain of FVC data to obtain a time invariant metric, same approach taken for the annual estimates of the metrics derived from FVC (see Sec. 3).

\section{Methodology}

The derivation of the ecohydrological metrics is based exclusively on the daily FVC time series. The method can be divided into four main steps: (i) masking and retrieval of minimum and maximum $\mathrm{FVC}\left(F V C_{\min }\right.$ and $\left.F V C_{\max }\right)$, (ii) detection of start and end of the decay periods, (iii) estimation of the decay period FVC integral $\left(I_{d p}\right)$, and (iv) estimation of the FVC decay rate during dry-down $(\lambda)$. Each methodological step is described in detail in the following subsections together with the final products, and their quality diagnostics when needed.

\subsection{Masking and Retrieval of FVC Extrema}

To remove the effect of outliers within a time series, we selected the 2 nd and 98th percentiles of the entire records of the FVC data as the minimum $\left(F V C_{\min }\right)$ and the maximum asymptotic values $\left(F V C_{\max }\right)$. To maintain a reliable signal-to-noise ratio before taking further steps, we filtered out any grid cell if $F V C_{\max }<0.1$ or more than one-third of the time series were missing. Due to the simplicity of the derivation of $F V C_{\min }$ and $F V C_{\max }$ metrics, quality diagnostics were deemed unnecessary, and not derived in this set of metrics.

\subsection{Detection of Decay Periods}

The detection of the decay period was based on a procedure using the first derivative of the smoothed FVC $\left(V^{\prime}\right)$ (see Algorithm 1). We smoothed daily time series of the FVC with a 31-day moving average $\left(V_{s m}\right)$. Then each day in the time series was marked as decay, growth or stable. To do so, we set two thresholds for decay and growth periods as $t h_{\text {decay }}$ and $t h_{\text {growth }}$, respectively. After rigorous investigation of time series of individual grid cells, we used the 75th and 70th percentiles of the negative derivative $\left(V^{\prime}\right)$ as thresholds $t h_{\text {decay }}$ and $-t h_{\text {growth }}$ for each grid cell. The magnitude $t h_{\text {decay }}$ is, thus, bigger than $t h_{\text {growth }}$, in accordance with the larger gradient in the beginning of the period than the end. Only the magnitude of $t h_{\text {growth }}$ was taken as a positive threshold to detect the increase in FVC.

An observation was considered as decay if $V^{\prime}<t h_{\text {decay }}$, growth if $V^{\prime}>t h_{\text {growth }}$, and stable if $t h_{\text {decay }} \leq V^{\prime} \leq t h_{\text {growth }}$. The resulting time series of classes (decay, growth, or recovery) were then smoothed by retaining the majority of decay and stable against recovery within a 5-day moving window. Complete decay period, which is considered as 
the initial decay period followed by a stable, non-increasing period, was then identified as the period from the beginning of a decay to the end of a stable period. In order to ensure robustness of the end of the stable period, especially in hyper-arid regions with poor signal-to-noise ratio, we extended the detected decay periods until the next significant increase in $V_{s m}$ (> $>$ \% of the corresponding seasonal amplitude of FVC). Note that selection of the thresholds and the moving window sizes were based on extensive exploration and visual inspection of the FVC time series. This was a necessary step to ensure the robustness against noise in the data, as well to address the diversity of FVC dynamics across African ecosystems. To highlight the complexity, some representative time series of FVC in selected grid cells across different climatological aridity are included in Appendix B, together with soil moisture and precipitation time series.

After detection of all decay periods in the time series, we only selected the longest one per calendar year. This is necessary for regions where vegetation may potentially have two growing (and decaying) seasons within a year. The longest decay period within a year is likely to be the most indicative of the largest water limitation, and the underlying ecohydrological mechanisms. When the detected decay period spanned over two calendar years, it was assigned as the decay period of the starting year. In total, the decay period detection algorithm (Algorithm 1) yielded 16,423,339 decay periods in 1,029,847 grid cells.

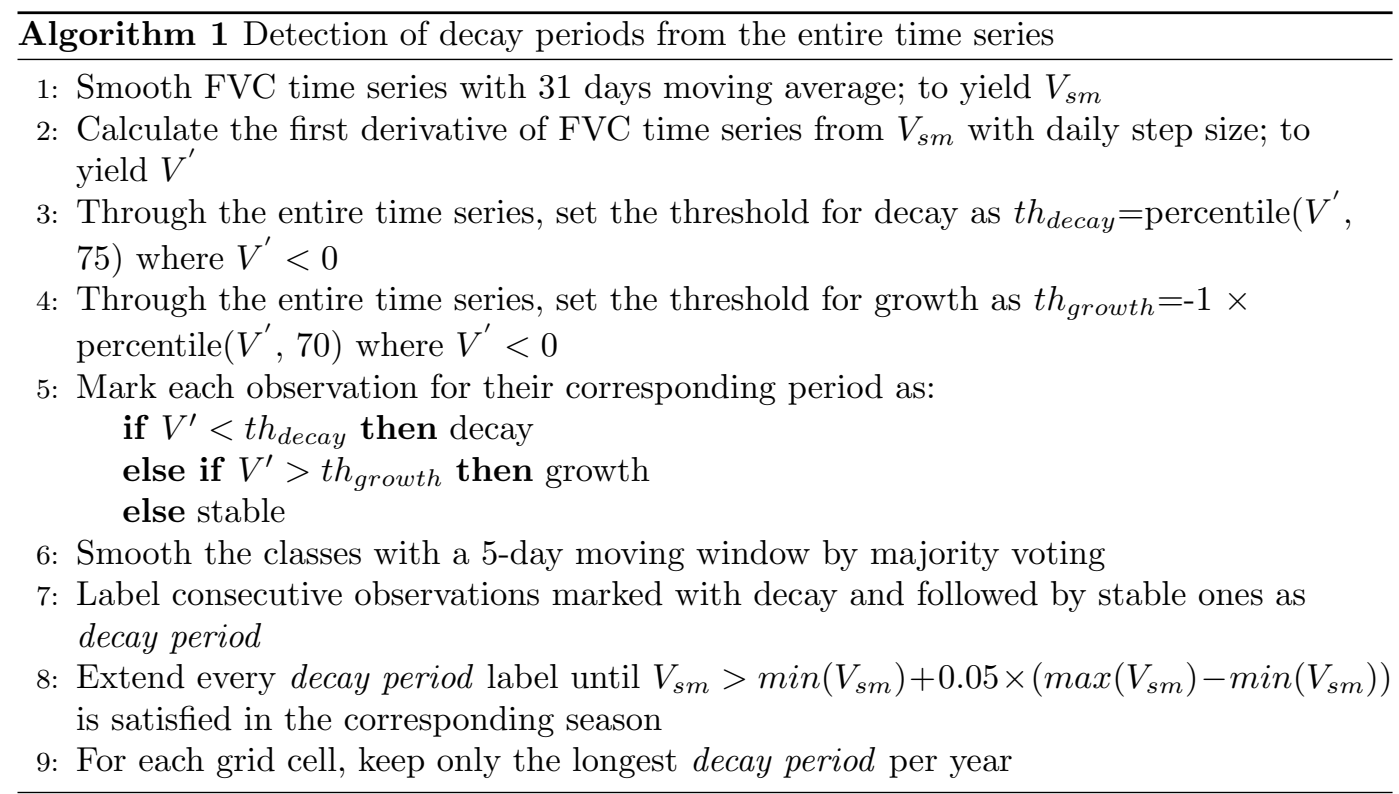

\subsection{Estimation of the Integral over FVC Decay}

We calculated the integral of FVC during decay period $\left(I_{d p}\right)$ as the total area under the FVC time series from the start to end of the decay period, with the area under $F V C_{\min }$ removed. This can be expressed as,

$$
I_{d p}=\sum^{\text {decayperiod }}\left(F V C(t)-F V C_{\text {min }}\right)
$$

Removal of the baseline FVC value $\left(F V C_{\min }\right)$ enhances the signal of seasonal decay of vegetation with respect to baseline vegetation activity. Note that, upon necessity, the full integral (total area under the curve) can be calculated as the sum of $I_{d p}$ and multiplication of decay period duration with minimum FVC $\left(D \times F V C_{m i n}\right)$. 
From the yearly dry season detection, 16 (the number of years) values of $I_{d p}$ were computed for each grid cell. We selected the median of the 16 values as the representative inference to be used for spatial analyses. The median was preferred over the mean to make the estimation robust against annual variations, for instance, by intermittent rain events in the dry season or issues related to FVC derivation. In addition, we also calculate and report the normalised robust Standard Error $(S E)$ as an indicator of variability. The SE is calculated as,

$$
S E=\frac{S D_{n}}{\sqrt{n}}
$$

where $S D_{n}$ is the robust standard error, calculated from the Median Absolute Deviation (MAD) across years (with the assumption of a normal distribution, Rousseeuw $\&$ Croux, 1993), and corrected for the low number of samples $(n=16)$ as:

$$
S D_{n}=M A D \times 1.4826 \times \frac{n}{n-1}
$$

The robust standard error reflects variability of the metrics among years as well as methodological uncertainty, and is therefore suitable for customised filtering in the context of spatial analysis.

\subsection{Estimation of FVC Decay Rate}

Temporal decay of the FVC can be characterised using an exponential function as,

$$
F V C(t)=\left(F V C_{d d}-F V C_{m i n}\right) \times e^{-t / \lambda}+F V C_{\text {min }}
$$

where $F V C_{d d}$ is the initial FVC value in the beginning of a dry-down, and $\lambda$ is the $e$-folding time (in days). Note that $\lambda$ is merely an inverse of the exponential decay rate. The formulation in Eq. 4 uses $\lambda$ as it is easier to interpret. In simple terms, $\lambda$ denotes the number of days needed to have a decrease in the seasonal amplitude of $\mathrm{FVC}\left(F V C_{d d}-\right.$ $\left.F V C_{\min }\right)$ to $1 / e$ of its original value during a dry-down event. Note that the selected exponential decay function explicitly takes an asymptotic minimum value of the FVC, as $F V C_{\text {min }}$, into account while estimating the decay rate (see Sec. 3.1) since $F V C_{\text {min }}$ is included in the formulation (Eq. 4).

Due to the S-shaped character of temporal vegetation dynamics, functions allowing different convexity, e.g., logistic functions, have been used to characterise these dynamics (Beck et al., 2006). As exponential decay functions are strictly convex, the concave part of the decay, which is mostly observed in the beginning of the decay period, is not considered for this metric. The latter part of the decay period, with convex curvature (i.e.: the first derivative is negative while the second is positive), is labelled as 'drydown' during the decay period. To define the dry-down period, we first discarded the time steps with concave observations (negative first and negative second derivative). Afterwards, we filtered out the convex observations before the inflection point of the FVC, that mostly associated with low signal-to-noise ratio at the beginning of the dry-down. Once daily observations are marked as convex or concave, we searched for local minimum of $V^{\prime}$ in the first third of the dry season, and identified the inflection point as the start of the dry-down. Note that, in the above process, second derivative of the FVC ( $\left.V^{\prime \prime}\right)$ was also smoothed with a 31-day moving window.

This procedure effectively removes observations with concave shape in the dry season, especially at the beginning of an event. For each event, if more than half of the data points showed convexity, we estimated $\lambda$, together with $F V C_{d d}$, based on an asymptotic 


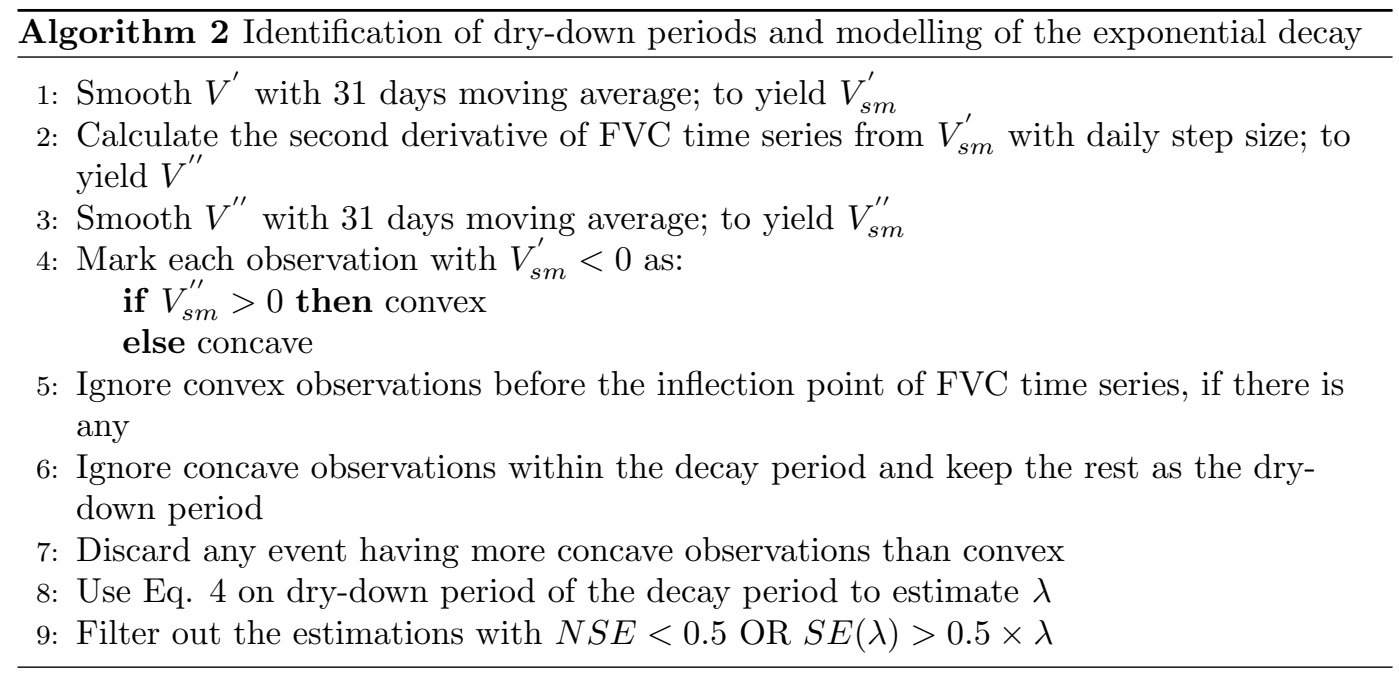

regression model that minimises least squares error with the Levenberg-Marquardt algorithm (Moré, 1978; Elzhov et al., 2016). We used both the Nash-Sutcliffe modelling efficiency (NSE; Nash \& Sutcliffe, 1970) and the standard error of the model $\left(S E_{m}\right)$ to assess the estimates of the model fitting. From the multiple $\lambda$ estimates, only those with successful convergence of the Levenberg-Marquardt algorithm with NSE $>0.5$ and $S E_{m}(\lambda)<$ $0.5 \times \lambda$ were accepted, the median of which was taken as the representative final $\lambda$ for a grid cell.

After defining the final $\lambda$, we estimated the variation as done in Sec. 3.3. Unlike in Sec. 3.3, the sample size per grid cell ( $n$ ) may change, as $\lambda$ estimation may not converge in cases with high noise. We, therefore, also report the number of successful convergences of the Algorithm 2 as an additional quality diagnostic that can be used for filtering $\lambda$ (mapped in Fig. H1).

\section{Results and Discussion}

In this section, we present and discuss the ecohydrological metrics derived in this study. For each metric we show the spatial variation in continental scale by maps along with zoomed inset plots (see Appendix $\mathrm{E}$ for further information and visual impression by corresponding Google Earth cut-outs) to visualise regional variability. Box plots of metrics per mean annual root-zone soil moisture show first order variations while heatmaps show sensitivity of these first order variations to different parameters addressing the hypotheses given in Sec. 1 (see Sec. 2.2 for the details of the data). Here we present the metrics independently, but we summarise their cross-comparison with a density plot in Fig. C1.

\subsection{FVC Extremes}

Spatial distributions of $F V C_{\min }$ and $F V C_{\max }$, histograms of the distribution over the full domain, and six zoomed insets focusing on selected regions are shown in Fig. 2a and $2 \mathrm{~b}$, respectively (see Fig. $\mathrm{F} 1$ for the seasonal dynamics expressed as $F V C_{\max }-F V C_{\min }$ ). At the continental scale, both $F V C_{\min }$ and $F V C_{\max }$ follow the moisture gradient with the highest and the lowest values in humid and arid regions, respectively. Saturation in the increase of $F V C_{\max }$ (Fig. 2c) in semi-arid regions suggests that water does not severely limit the vegetation cover at the peak of the wet season in regions with intermediate to high mean annual soil moisture values (see Fig. E1 for map of mean annual root-zone soil moisture as an indicator of climatological aridity together with Google Earth views 



$\lambda$ can corroborate the rate of decrease of plant available water, ecosystem scale water use efficiency, and the propensity to senescence. Ecosystems differ widely in their water use strategies, from being water conservative - typically associated with strong downregulation of stomatal conductance with water deficiency - to aggressive exploitation of water resources (Laio et al., 2001). Herbaceous plants are typically aggressive water users and cease with the depletion of surface soil moisture. Woody plants risk cavitation and death under severe water stress, and such, trees in places with frequent dry periods benefit from a water saving strategy or senescence for prolonged periods. Konings and Gentine (2017) inferred ecosystem water-use strategies globally based on diurnal variations of vegetation optical depth assuming that those reflect stomatal regulation to maintain leaf-water potential. They found an increase in isohydricity, i.e. the degree of stomatal regulation and subsequent water savings, with increase in vegetation height, consistent with the need of tall trees to prevent hydraulic failure during drought. Teuling et al. (2006) characterised decay rate in land evaporation (soil evaporation and transpiration) under water limitation using flux tower measurements and found that sites with stronger seasonality and larger woody coverage have slower decays. This association is confirmed by similar studies, for seasonality and canopy height (Boese et al., 2019), and for trees than grasses (Martínez-de la Torre et al., 2019). Slower decay of land evaporation of taller/woody canopy despite the faster decay of soil moisture with stronger aridity (McColl et al., 2017) suggests reduced transpiration or other plant adaptation mechanisms.

If the rate of FVC decay was also related to ecosystems' water use strategy in a similar manner, we would expect slower FVC decay (higher $\lambda$ ) with increasing canopy height. In arid and semi-arid regions, we indeed find a tendency of increasing $\lambda$ with canopy height except very tall canopy (Fig. 6b), suggesting that $\lambda$ incorporates ecosystem water use strategy traits as well as direct or indirect effects of soil moisture therein. However, as the climate gets wetter $\lambda$ tends to decrease with canopy height. A possible explanation would be the changes in the drought coping strategies in ecosystem scale (Singh et al., 2020), or that water consumption, i.e. transpiration, increases with canopy height resulting in a faster depletion of moisture storage (Koirala et al., 2017), or increasing ecosystem water use efficiency with aridity.

Sensitivity of the nonlinear relationship between $\lambda$ and climatological aridity to tree cover (see Fig. 6b) shows that $\lambda$ systematically increases with larger tree cover values in arid and semi-arid systems, with peak values observed in semi-arid regions with 26$43 \%$ of tree cover which overlaps with the reported interval for the transition between highly water-stressed forest and savanna (Singh et al., 2020). However this trend is inverted moving towards regions with weaker water-stress, hence denser tree cover, which agrees with Singh et al. (2020) as moderately or lowly water-stressed forests do not develop strong adaptation against water limitation, nor change canopy structure. The agreement among these two studies having different methodologies shows the value of the observationdriven metric $\lambda$ to gain ecohydrological insights and have a better understand in vegetationwater dynamics.

\section{Conclusions}

Using retrievals of the SEVIRI sensor of the geostationary satellite MSG, we derived ecohydrological metrics for continental Africa entirely from the temporal dynamics of the daily Fraction of Vegetation Cover (FVC) time series from 2004 to 2019 at ca. $5 \mathrm{~km}\left(0.0417^{\circ}\right)$ spatial resolution. Our metrics captures both continental scale gradients and covariations with climate as well as structured regional variations, e.g. due to topographic factors. This provides an unprecedented opportunity to improve our understanding of ecohydrological processes across spatial scales over Africa.

The minimum asymptotic value of vegetation cover $\left(F V C_{\min }\right)$ can be used to diagnose riparian corridors, seasonal wetlands and floodplains in arid and semi-arid regions 



\section{Acknowledgments}

Çağlar Küçük acknowledges funding from the International Max Planck Research School for Global Biogeochemical Cycles. Diego G. Miralles acknowledges funding from the European Research Council (ERC) under grant agreement 715254 (DRY2DRY) and the European Union Horizon 2020 Programme project 869550 (DOWN2EARTH). 


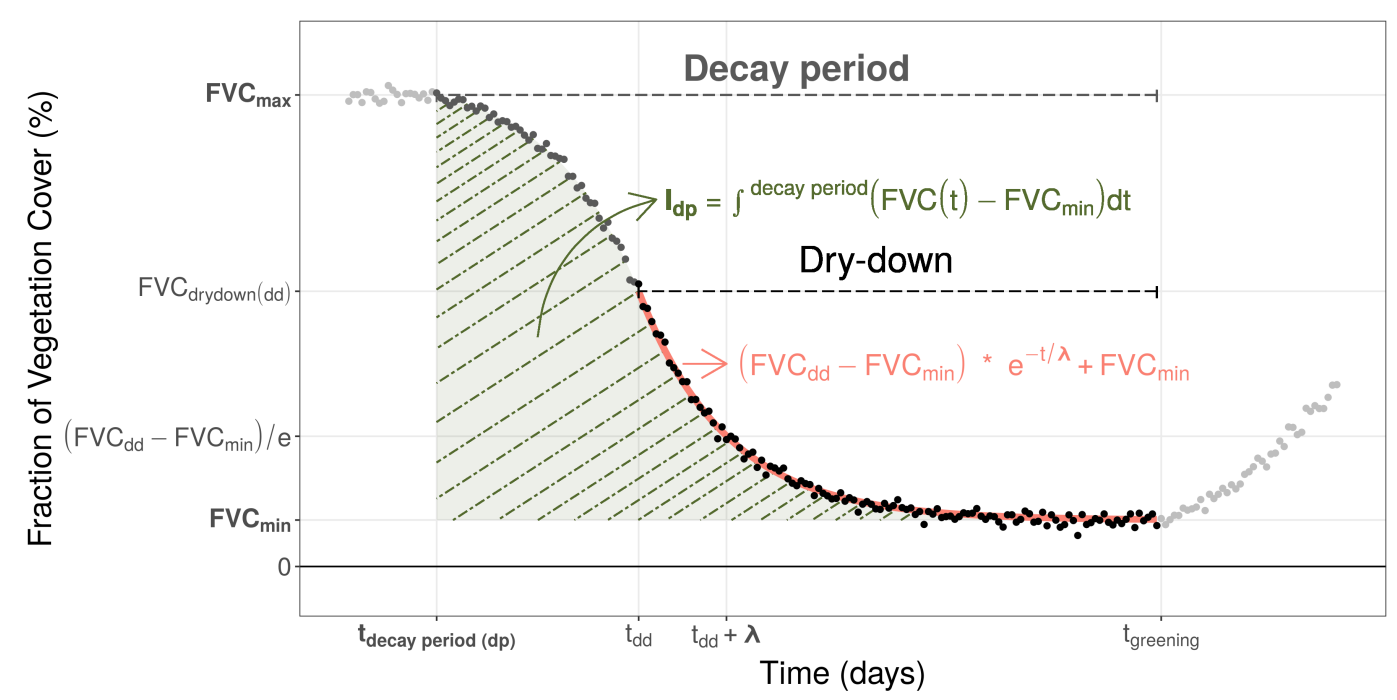

Figure 1: Conceptual plot of the ecohydrological metrics derived from time series using synthetic data. Points represent observations for growing period, early decay period and decay period with dry-down in light grey, grey and black, respectively. Decay and growth periods are defined by presence of decay, i.e., first derivative of the time series, while drydown period is defined by the convexity of the decay, i.e., using both first and second derivatives (see Sec. 3.4 for details). The shaded area shows the integral of FVC during decay period. The red curve shows the fitted line on the FVC time series during dry-down using the asymptotic exponential decay function. All metrics presented in this study are shown in bold characters. 


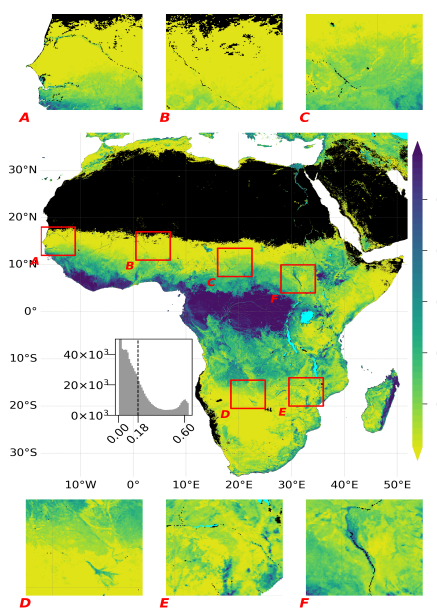

(a)

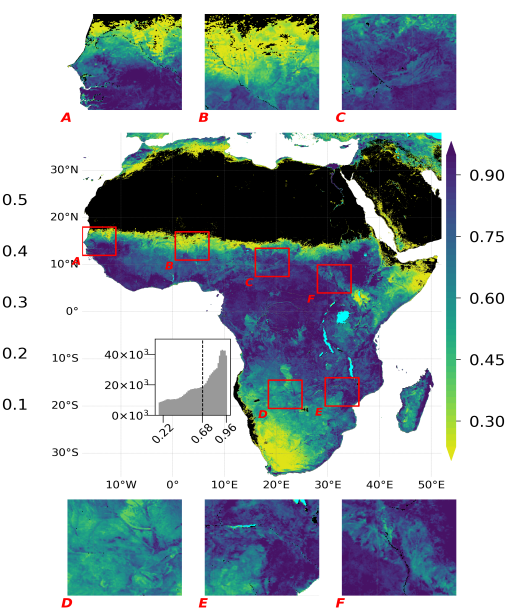

(b)

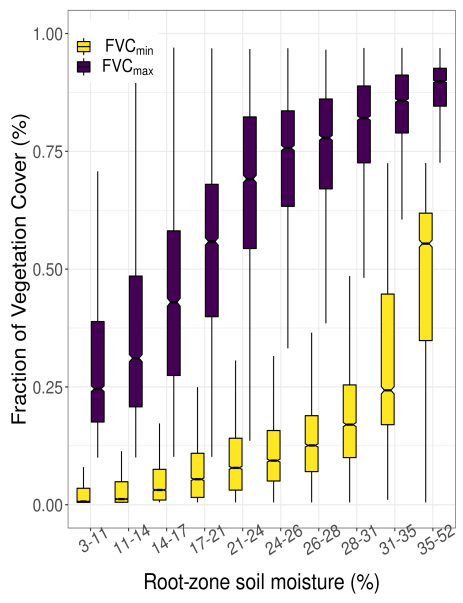

(c)

Figure 2: (a) Minimum asymptotic values of $\mathrm{FVC}, F V C_{m i n}$, (b) maximum asymptotic values of FVC, $F V C_{\max }$, (c) box plot showing the variation of $F V C_{\min }$ and $F V C_{\max }$ with mean annual soil moisture. In the maps, histogram of the metrics mapped can be seen inside the main panel, with a dashed line indicating the mean values of the domain, as well as six insets to show local variability (See Appendix E for details of the insets). In all of the following box plots, binning of soil moisture is done automatically to equalise frequency of observations among the bins while median values per each bin are shown in the intermediate line of the boxes, with their $95 \%$ confidence intervals notched. Upper and lower edges of the boxes show the interquartile range (75th and 25th percentiles, respectively) while the error bars show 1.5 times the interquartile range.

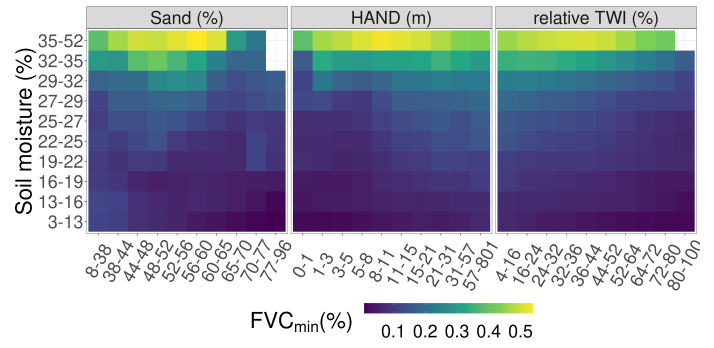

(a) $F V C_{\min }$

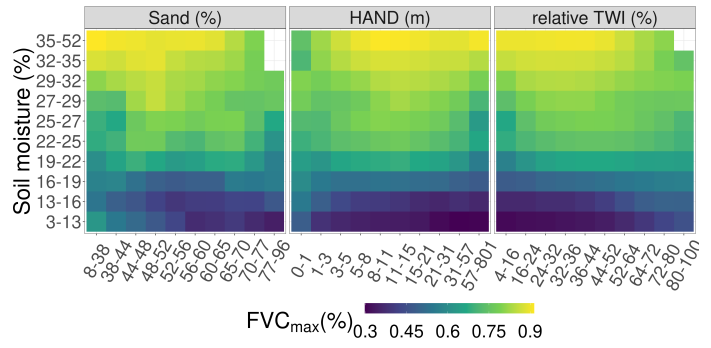

(b) $F V C_{\max }$

Figure 3: Covariation of asymptote-related metrics and root-zone soil moisture with sand percentage, HAND, and TWI. Note that binning of the continuous variables in $\mathrm{x}$ - and $\mathrm{y}$-axes are done automatically to equalise frequency of observations among the bins of a given variable. 


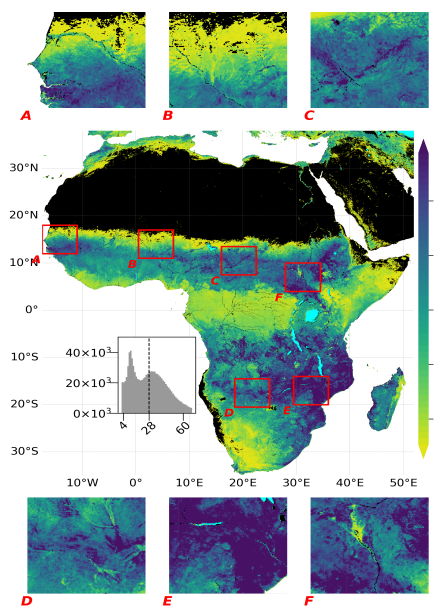

(a)

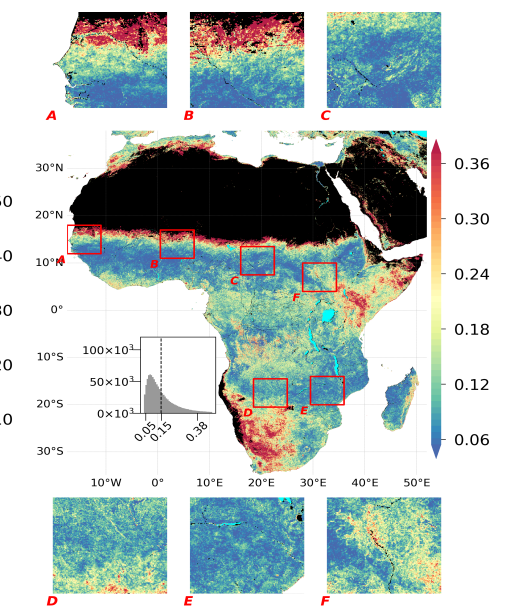

(b)

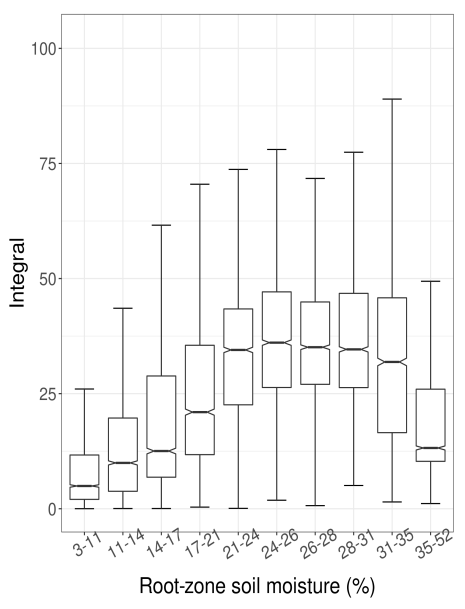

(c)

Figure 4: (a) Integral of FVC time series in the decay period, $I_{d p}$, (b) variation of $I_{d p}$, (c) distribution of $I_{d p}$ within mean annual soil moisture. See Fig. 2 for plotting details.

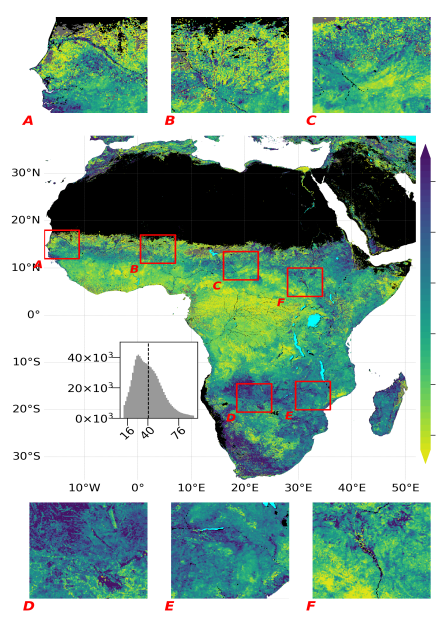

(a)

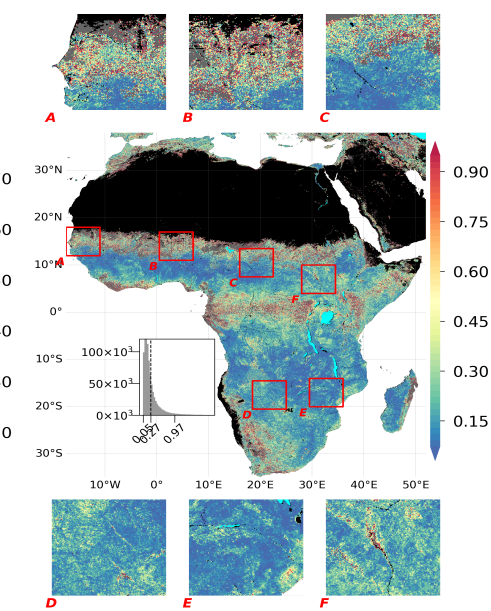

(b)

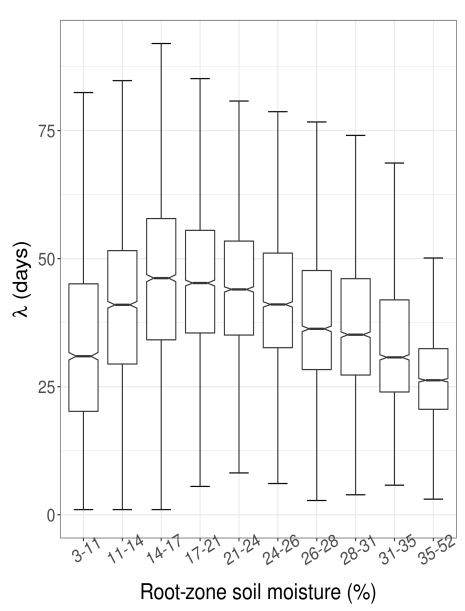

(c)

Figure 5: (a) $e$-folding time of FVC time series during dry-down (in days), $\lambda$, (b) variation of $\lambda$, (c) distribution of $\lambda$ within soil moisture. See Fig. 2 for plotting details. 


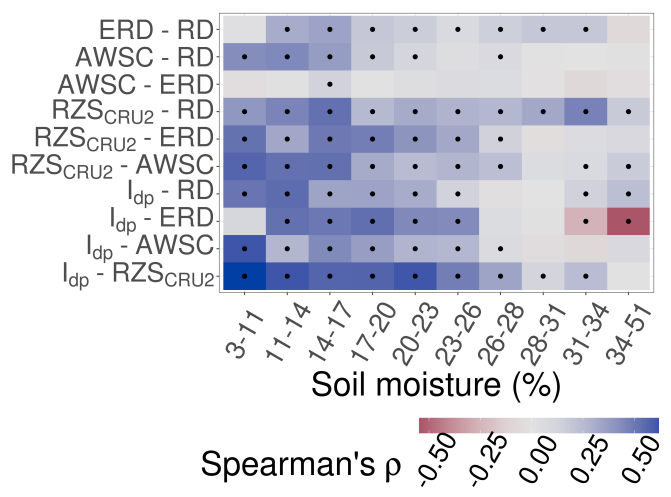

(a)

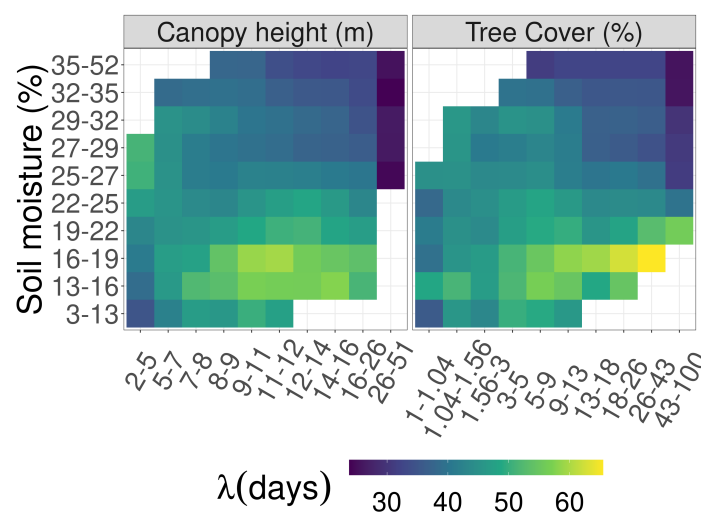

(b)

Figure 6: (a) Spearman's correlation coefficients between pairs of products related to plant accessible water content, namely Effective Rooting Depth (ERD) from Yang et al. (2016), Rooting Depth (RD) from Fan et al. (2017), Accessible Water Storage Capacity (AWSC) from S. Tian et al. (2019), Root Zone Storage Capacity $\left(R Z S_{C R U 2}\right)$ from Wang-Erlandsson et al. (2016), and integral of FVC during decay period $\left(I_{d p}\right)$ presented in this study. Black dots indicate significant correlation with $\rho>0.05$. (b) Covariation of $\lambda$ and root-zone soil moisture with canopy height, and tree cover. Note that binning of soil moisture, canopy height and tree cover are done automatically to equalise frequency of observations among the bins of the given variable. 


\section{Appendix A An Example Map of the Original FVC Data for a Sin-} gle Day

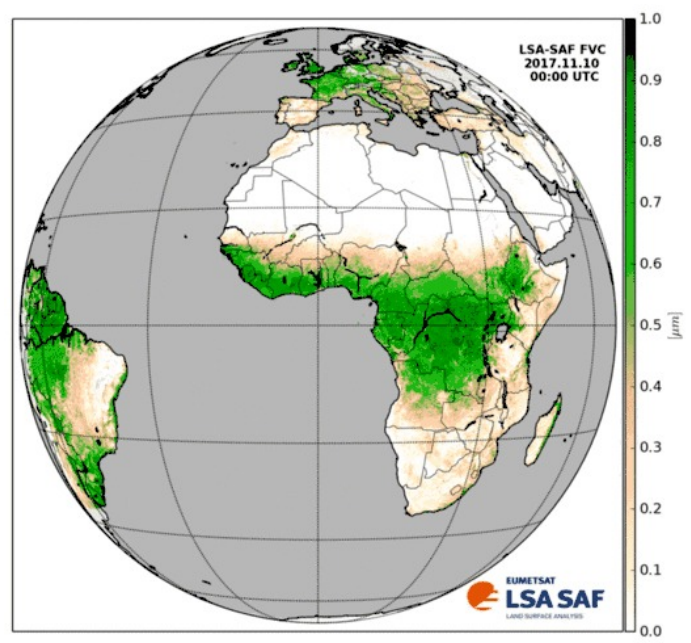

Figure A1: The original FVC data product for a single day, taken from https://landsaf.ipma.pt/en/products/vegetation/fvc/ 


\section{Appendix B Time Series of FVC in Example Grid Cells}

In this subsection; we present 5 years time series of selected grid cells from each bin of mean annual soil moisture values given in the main manuscript to demonstrate the results of the algorithms in grid cell scale.

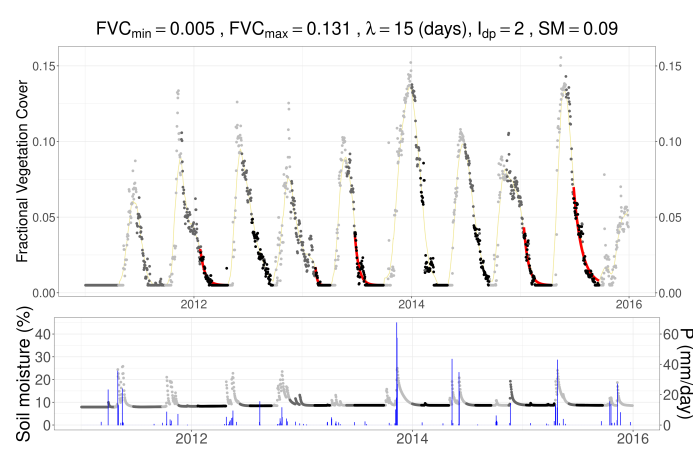

(a)

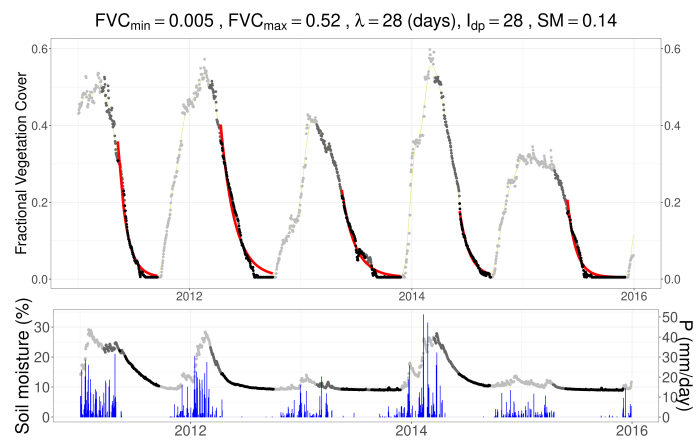

(c)

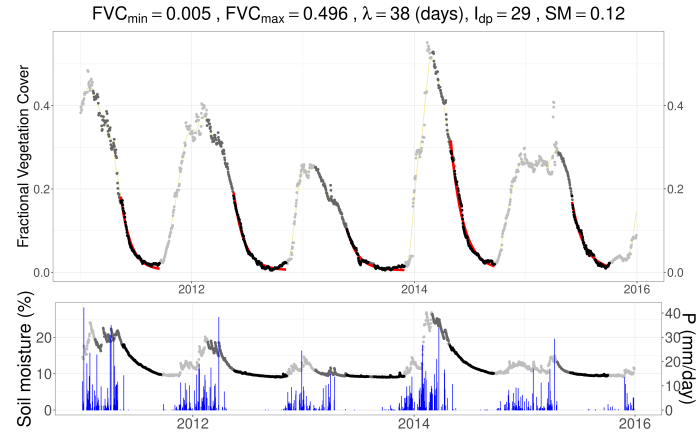

(b)

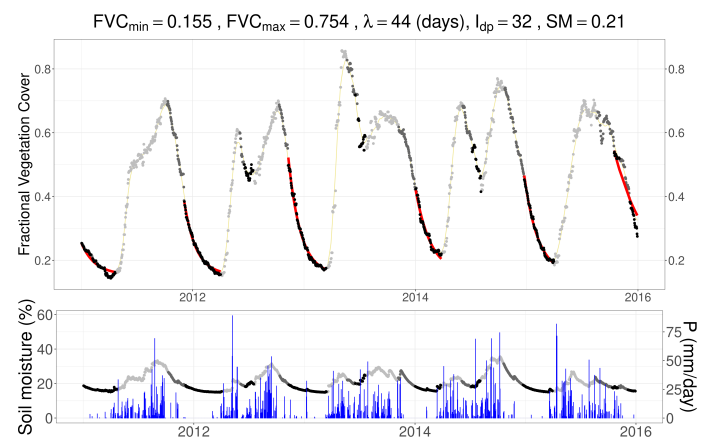

(d)

Figure B1: FVC, soil moisture, and precipitation time series of sampled grid cells. Sampling is done to have one grid cell per each bin of soil moisture values given in the plots of the main manuscript. Points for both FVC and soil moisture are coloured according to the state of vegetation activity as growing period is shown in light grey, decay period with dark grey while dry-down during the decay period is shown in black. Fitted curve to estimate $\lambda$ is shown with red lines while 31-day smoothed FVC values are shown in orange lines at the upper panel, while daily precipitation values are shown with blue bars at the lower panel. Note that daily aggregated precipitation data is obtained from Tropical Rainfall Measuring Mission (TRMM) (2011). 


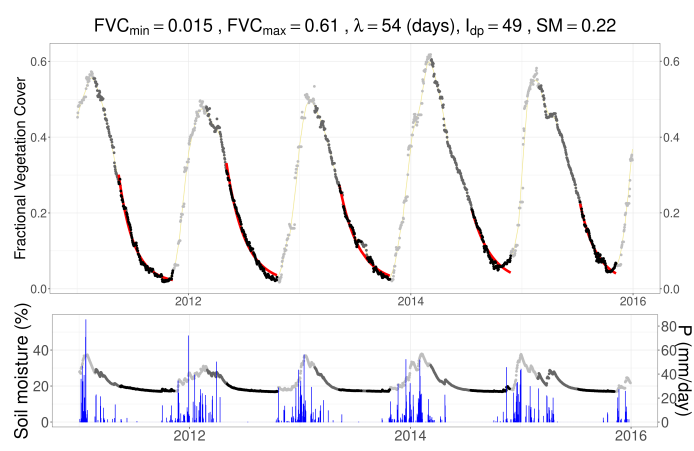

(a)

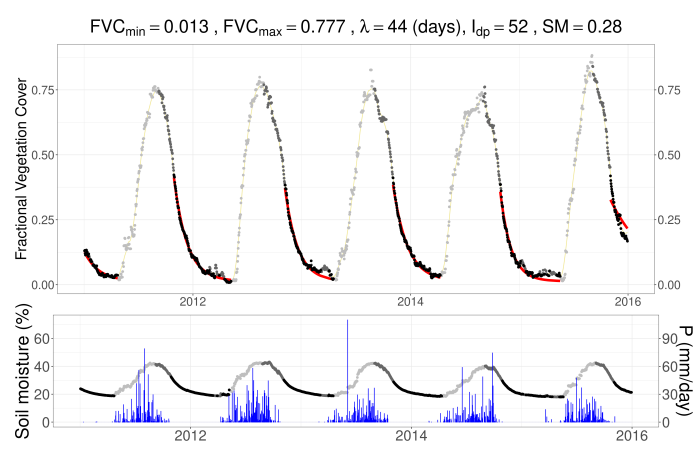

(c)

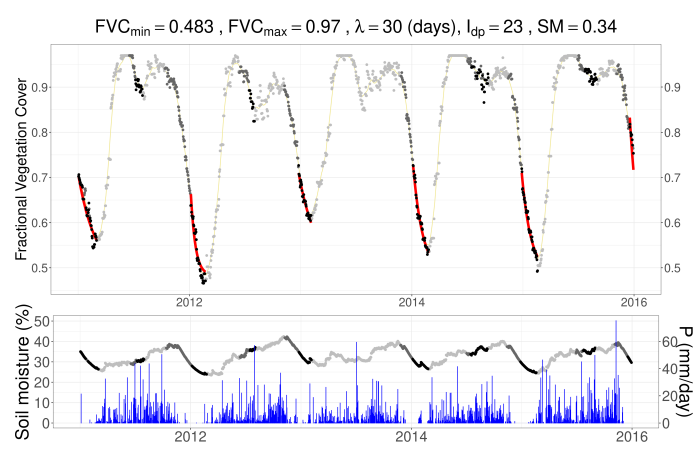

(e)

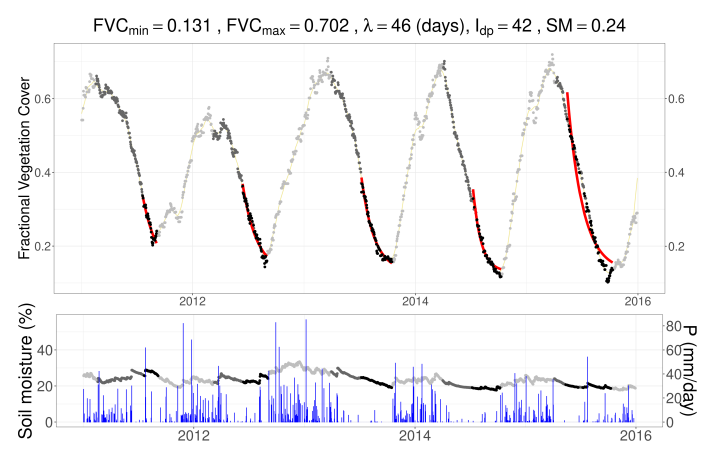

(b)

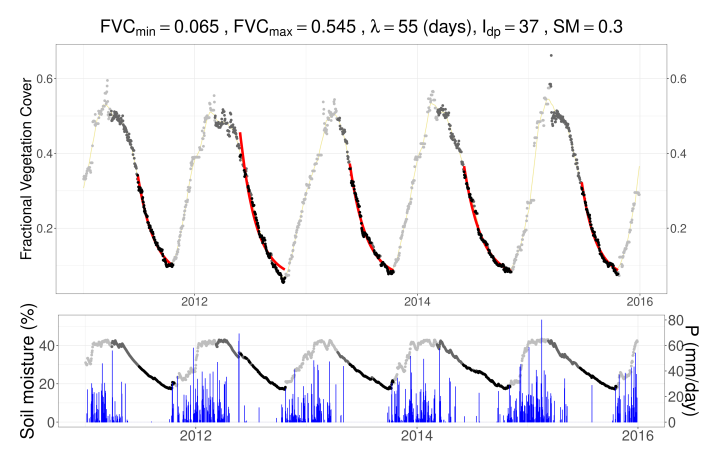

(d)

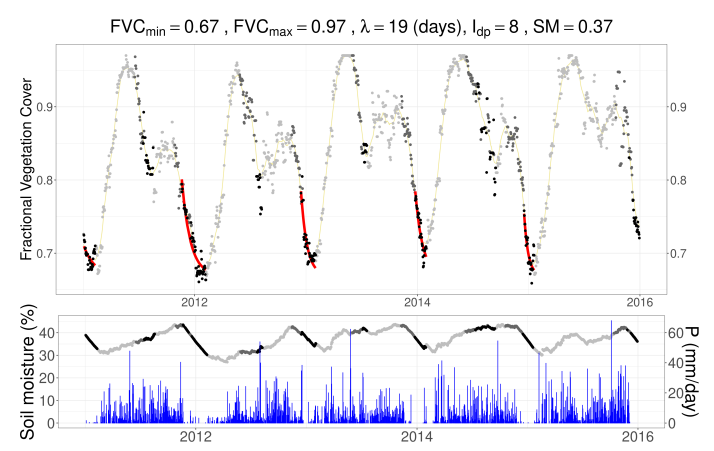

(f)

Figure B2: Continuation of Fig. B1 with samples having larger mean annual soil moisture. 
728

\section{Appendix C Density Plots of the Ecohydrological Metrics}
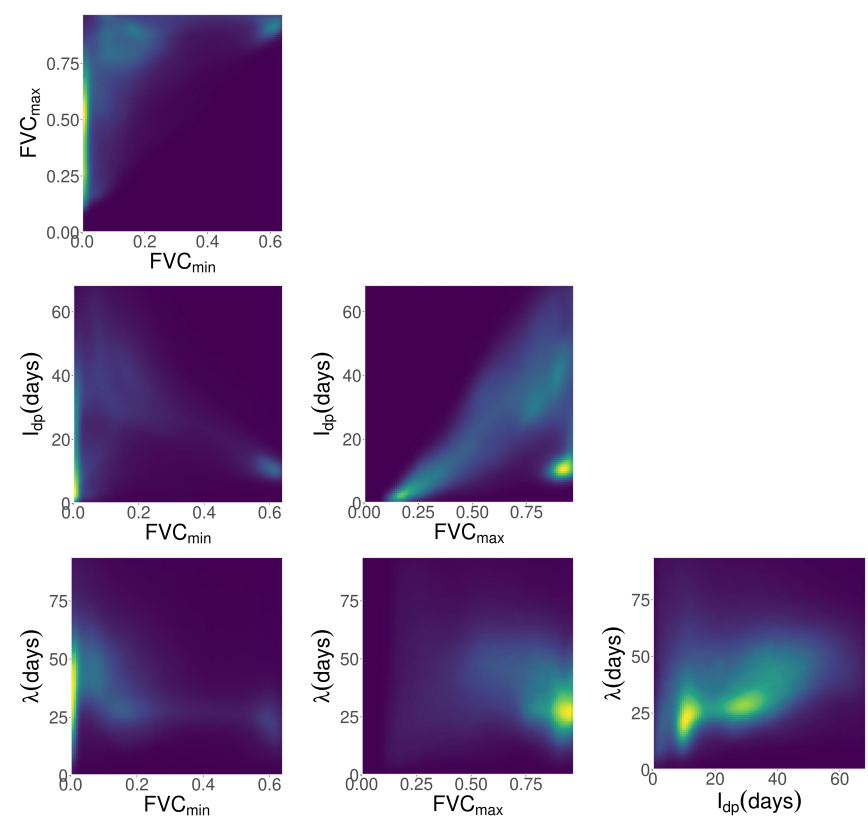

Figure C1: Density plots of the ecohydrological metrics presented in this study. 
729

\section{Appendix D Temporal Correlation Between FVC and Soil Moisture}

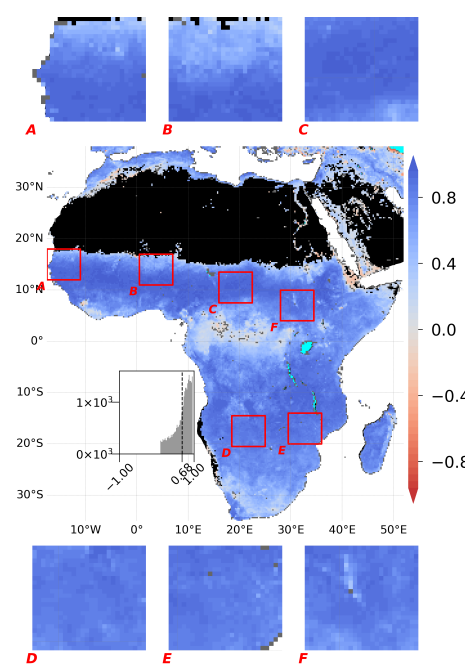

(a)

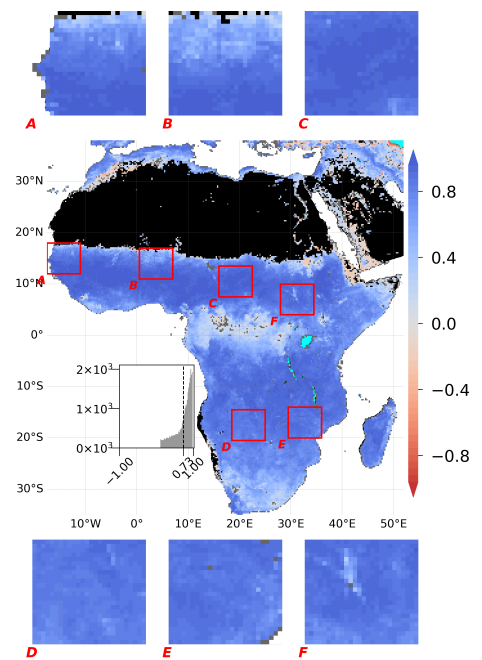

(b)

Figure D1: Pixelwise Spearman's correlation of FVC and GLEAM root-zone soil moisture in time for (a) entire time series, (b) time series marked as decay period using FVC. 


\section{Appendix E Map of Climatological Aridity and Google Earth View of Insets}

Fig. E1 shows the continental map of mean annual root-zone soil moisture (\%) from GLEAM and the Google Earth views of the insets. Note that soil moisture values are binned to have equal number of observations in each class. Box-A: the Gambia and large portion of the Senegal rivers; Box-B: a small area of the Niger river mostly showing the transition from the Sahara desert to Sahel; Box-C: more on the transition from Sahel to tropical regions; Box-D: located in one of the most complex regions of Africa in terms of topography and lateral flow of water with lower sections of the Okavango and the Cuando rivers and upper section of the Zambezi river, together with multiple seasonally flooding areas like the Okavango delta, the Barotse Floodplain, and the Linyanti swamp. These seasonal wetlands are vital for the ecosystem and also provides great support against water limitation and heat for not only plants but also animals; Box-E: Lower Zambezi Basin together with the drainage of Lake Malawi to Zambezi. It also covers the Inyanga mountains located between Mozambique and Zimbabwe where a climatic shift happens over the mountain range. Last but not least, Box-F: largely covered by tropical savanna, is divided by the White Nile from South to North, covers the Sudd swamp.

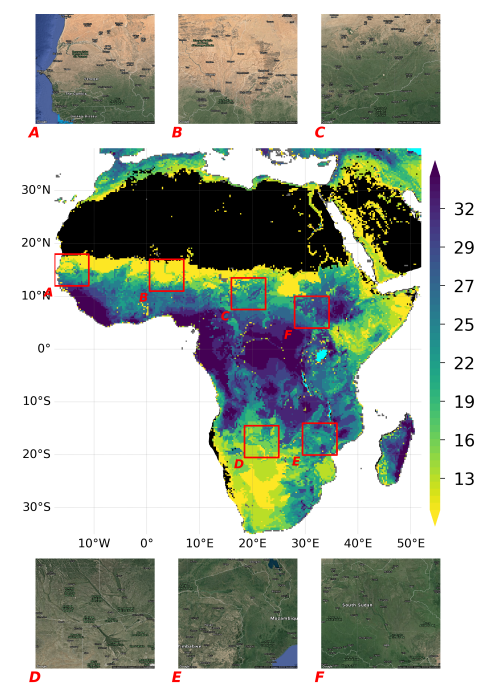

Figure E1: Map of mean annual root-zone soil moisture (\%) in the centre and satellite view of the insets. Map and image data of the insets: Google Earth (c)2020 TerraMetrics. 
Appendix F Summary of Seasonal Dynamics of FVC, FVC $C_{\text {range }}$

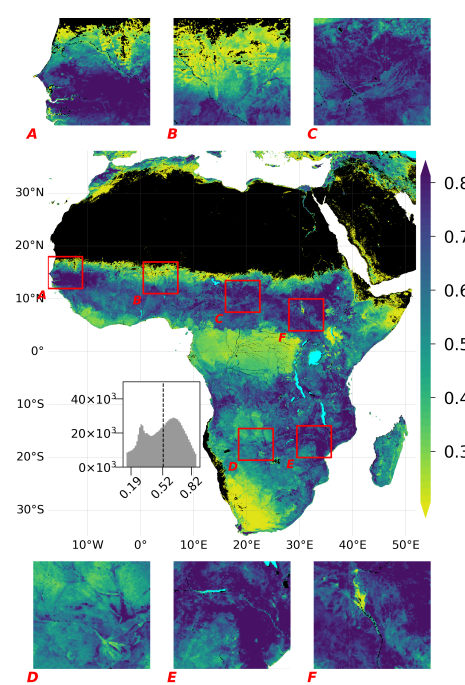

(a)

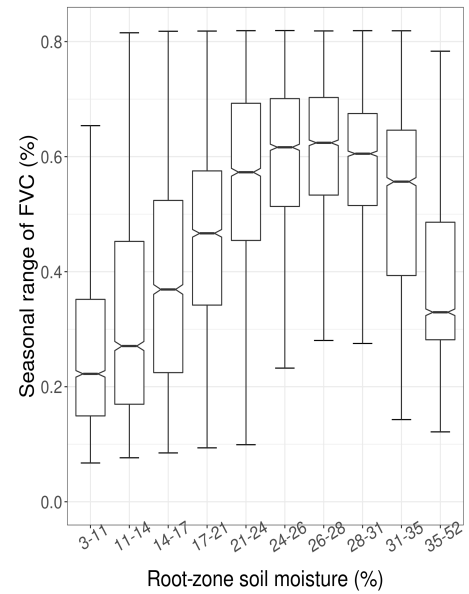

(b)

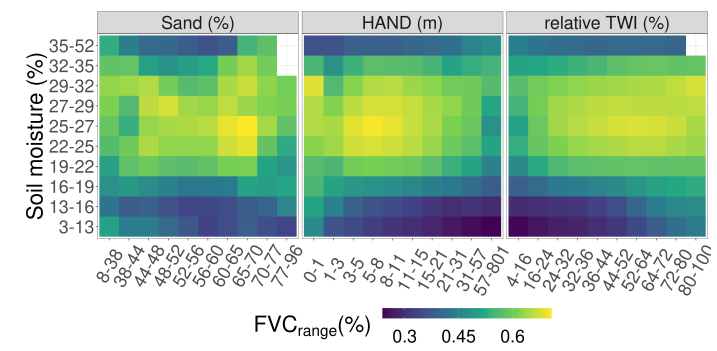

(c)

Figure F1: Variations in $F V C_{\text {range }}$ (as $F V C_{\max }-F V C_{\min }$ ) (a) in space (b) with climatological aridity (c) similar to Fig. 3a but for $F V C_{\text {range }}$ 


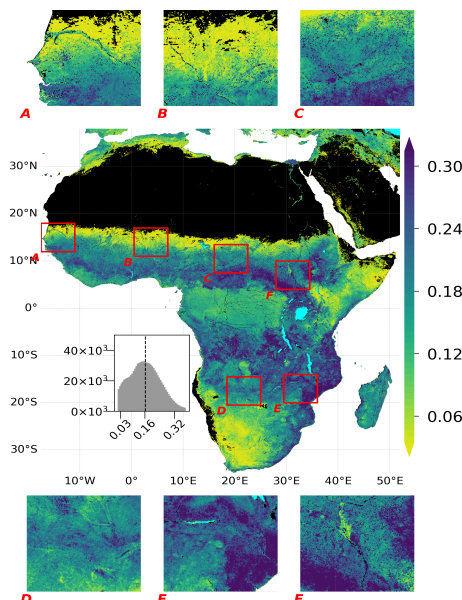

(a)

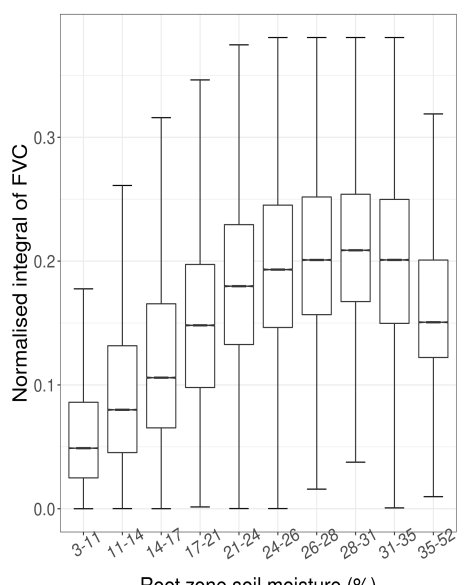

(b)

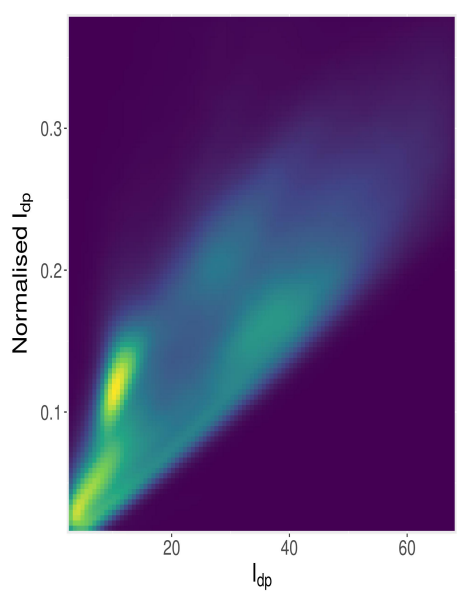

(c)

Figure G1: Integral of FVC time series in the decay period normalised by event duration (a) Spatial variation, (b) variation against within mean annual soil moisture (see Fig. 2c for plotting details). (c) density plot against $I_{d p}$

\section{Appendix H Map of Number of Convergences of Algorithm 2}

Appendix I Maps of Accessible Water Storage Capacity Datasets 


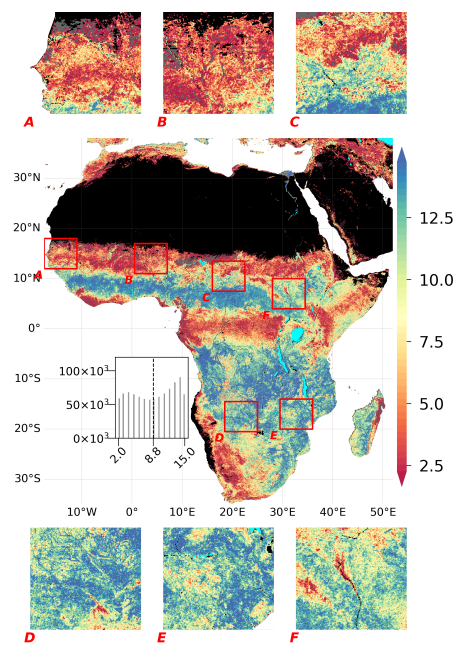

Figure H1: Number of decay periods in which the Algorithm 2 successfully converged.

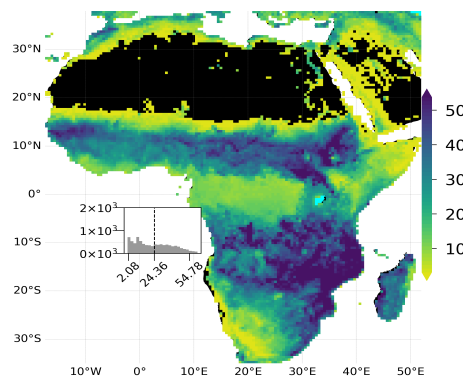

(a) $I_{d p}$

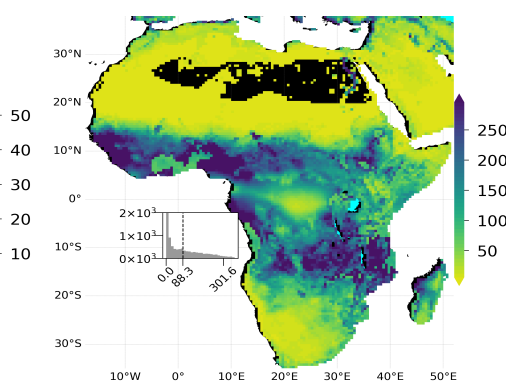

(b) $R Z S_{C R U 2}$

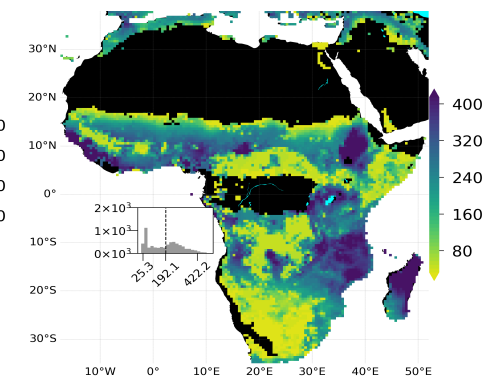

(c) AWSC

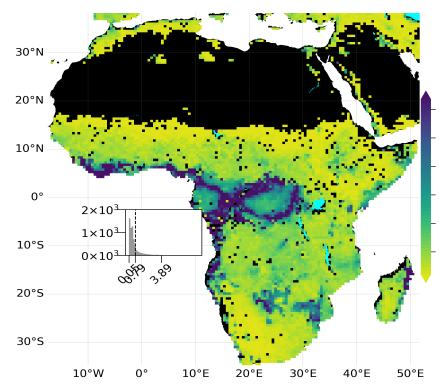

(d) ERD

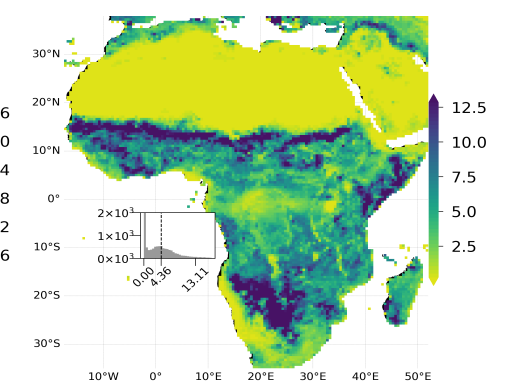

(e) $\mathrm{RD}$

Figure I1: Maps of accessible water storage capacity and rooting depth datasets used in this study. (a) Integral of FVC during decay period, $I_{d p}$, (b) Root Zone Storage Capacity $\left(R Z S_{C R U 2}\right)$ using CRU as precipitation forcing data with 2 years of drought return period from Wang-Erlandsson et al. (2016), (c) Accessible Water Storage Capacity (AWSC) from S. Tian et al. (2019) (d) Effective Rooting Depth (ERD) from Yang et al. (2016), (e) Rooting Depth (RD) from Fan et al. (2017). All products are aggregated to $0.5^{\circ}$ and cropped for the study domain. 


\section{References}

Adole, T., Dash, J., \& Atkinson, P. M. (2016). A systematic review of vegetation phenology in Africa. Ecological Informatics, 34, 117-128. doi: 10.1016/j.ecoinf .2016.05.004

Adole, T., Dash, J., Rodriguez-Galiano, V., \& Atkinson, P. M. (2019). Photoperiod controls vegetation phenology across Africa. Communications Biology, 2(1). doi: 10.1038/s42003-019-0636-7

Akasheh, O. Z., Neale, C. M., \& Jayanthi, H. (2008). Detailed mapping of riparian vegetation in the middle Rio Grande River using high resolution multi-spectral airborne remote sensing. Journal of Arid Environments, 72(9), 1734-1744. doi: $10.1016 /$ j.jaridenv.2008.03.014

Amatulli, G., McInerney, D., Sethi, T., Strobl, P., \& Domisch, S. (2020). Geomorpho90m, empirical evaluation and accuracy assessment of global highresolution geomorphometric layers. Scientific Data, 7(1), 1-18. doi: 10.1038/s41597-020-0479-6

Anderegg, W. R., Konings, A. G., Trugman, A. T., Yu, K., Bowling, D. R., Gabbitas, R., ... Zenes, N. (2018). Hydraulic diversity of forests regulates ecosystem resilience during drought. Nature, 561(7724), 538-541. doi: 10.1038/s41586-018-0539-7

Barron, O. V., Emelyanova, I., Van Niel, T. G., Pollock, D., \& Hodgson, G. (2014). Mapping groundwater-dependent ecosystems using remote sensing measures of vegetation and moisture dynamics. Hydrological Processes, 28(2), 372-385. doi: 10.1002/hyp.9609

Beck, P. S. A., Atzberger, C., Høgda, K. A., Johansen, B., \& Skidmore, A. K. (2006). Improved monitoring of vegetation dynamics at very high latitudes: A new method using MODIS NDVI. Remote Sensing of Environment, 100(3), 321-334. doi: 10.1016/j.rse.2005.10.021

Boese, S., Jung, M., Carvalhais, N., Teuling, A. J., \& Reichstein, M. Carbon-water flux coupling under progressive drought. Biogeosciences, 16(13), 2557-2572. doi: 10.5194/bg-16-2557-2019

Caylor, K. K., Manfreda, S., \& Rodriguez-Iturbe, I. (2005). On the coupled geomorphological and ecohydrological organization of river basins. Advances in Water Resources, 28(1), 69-86. doi: 10.1016/j.advwatres.2004.08.013

Caylor, K. K., Scanlon, T. M., \& Rodríguez-Iturbe, I. （2009). Ecohydrological optimization of pattern and processes in water-limited ecosystems: A trade-off-based hypothesis. Water Resources Research, 45(8), 1-15. doi: 10.1029/2008WR007230

Clark, M. P., Fan, Y., Lawrence, D. M., Adam, J. C., Bolster, D., Gochis, D. J., ... Zeng, X. (2015). Improving the representation of hydrologic processes in Earth System Models. Water Resources Research, 51(8), 5929-5956. doi: 10.1002/2015WR017096

Cronberg, G., Gieske, A., Martins, E., Prince Nengu, J., \& Stenström, I.-M. (1995). Hydrobiological studies of the Okavango Delta and Kwando/Linyati/Chobe River, Botswana I surface water quality analysis. Botswana Notes and Records, 27. Retrieved from http://www.jstor.org/stable/40980045

Dimiceli, C., Carroll, M., Sohlberg, R., Kim, D. H., Kelly, M., \& Townshend, J. R. G. (2015). MOD44B MODIS/Terra Vegetation Continuous Fields Yearly L3 Global 250m SIN Grid V006. NASA EOSDIS Land Processes DAAC. doi: 10.5067/MODIS/MOD44B.006

D'Odorico, P., Porporato, A., \& Runyan, C. W. (2019). Dryland ecohydrology. Springer International Publishing. doi: 10.1007/978-3-030-23269-6

Eamus, D., Zolfaghar, S., Villalobos-Vega, R., Cleverly, J., \& Huete, A. Groundwater-dependent ecosystems: Recent insights from satellite and fieldbased studies. Hydrology and Earth System Sciences, 19(10), 4229-4256. doi: 10.5194/hess-19-4229-2015 
Elzhov, T. V., Mullen, K. M., Spiess, A.-N., \& Bolker, B. (2016). minpack.lm: $\mathrm{R}$ Interface to the Levenberg-Marquardt Nonlinear Least-Squares Algorithm Found in MINPACK, Plus Support for Bounds [Computer software manual]. Retrieved from https://cran.r-project.org/package=minpack. Im

Epstein, H. E., Lauenroth, W. K., \& Burke, I. C. (1997). Effects of temperature and soil texture on ANPP in the U.S. Great plains. Ecology, 78(8), 2628-2631. doi: $10.2307 / 2265921$

Everitt, J. H., \& Deloach, C. J. (1990). Remote sensing of chinese tamarisk (tamarix chinensis) and associated vegetation. Weed Science, 38(3), 273278. doi: 10 $.1017 /$ S0043174500056526

Everitt, J. H., Judd, F. W., Escobar, D. E., Alaniz, M. A., Davis, M. R., \& Macwhorter, W. (1996). Using remote sensing and spatial information technologies to map sabal palm in the lower Rio Grande Valley of Texas. Southwestern Naturalist, 41(3), 218-226. Retrieved from http://www.jstor.org/ stable/30055117

Fan, Y., Clark, M., Lawrence, D. M., Swenson, S., Band, L. E., Brantley, S. L., ... Yamazaki, D. (2019). Hillslope hydrology in global change research and earth system modeling. $\quad$ Water Resources Research, 1737-1772. doi: 10.1029/2018WR023903

Fan, Y., Miguez-Macho, G., Jobbágy, E. G., Jackson, R. B., \& Otero-Casal, C. (2017). Hydrologic regulation of plant rooting depth. Proceedings of the National Academy of Sciences, 114(40), 10572-10577. doi: 10.1073/pnas.1712381114

Fernandez-Illescas, C. P., Porporato, A., Laio, F., \& Rodríguez-Iturbe, I. （2001). The ecohydrological role of soil texture in a water-limited ecosystem. Water Resources Research, 37(12), 2863-2872. doi: 10.1029/2000WR000121

Fisher, R. A., \& Koven, C. D. (2020). Perspectives on the future of Land Surface Models and the challenges of representing complex terrestrial systems. Journal of Advances in Modeling Earth Systems. doi: 10.1029/2018ms001453

GDAL/OGR contributors. (2020). GDAL/OGR geospatial data abstraction software library [Computer software manual]. Retrieved from https://gdal.org

Gentine, P., D’Odorico, P., Lintner, B. R., Sivandran, G., \& Salvucci, G. Interdependence of climate, soil, and vegetation as constrained by the Budyko curve. Geophysical Research Letters, 39(19), 2-7. doi: 10.1029/ 2012GL053492

Gond, V., Fayolle, A., Pennec, A., Cornu, G., Mayaux, P., Camberlin, P., ... Gourlet-Fleury, S. (2013). Vegetation structure and greenness in Central Africa from Modis multi-temporal data. Philosophical Transactions of the Royal Society B: Biological Sciences, 368(1625). doi: 10.1098/rstb.2012.0309

Guan, K., Medvigy, D., Wood, E. F., Caylor, K. K., Li, S., \& Jeong, S. J. (2014). Deriving vegetation phenological time and trajectory information over Africa using SEVIRI daily LAI. IEEE Transactions on Geoscience and Remote Sensing, 52(2), 1113-1130. doi: 10.1109/TGRS.2013.2247611

Guan, K., Pan, M., Li, H., Wolf, A., Wu, J., Medvigy, D., ... Lyapustin, A. I. (2015). Photosynthetic seasonality of global tropical forests constrained by hydroclimate. Nature Geoscience, 8(4), 284-289. doi: 10.1038/ngeo2382

Guan, K., Wolf, A., Medvigy, D., Caylor, K. K., Pan, M., \& Wood, E. F. Seasonal coupling of canopy structure and function in African tropical forests and its environmental controls. Ecosphere, 4(3), 1-21. doi: 10.1890/ES12-00232.1

Guan, K., Wood, E. F., Medvigy, D., Kimball, J., Pan, M., Caylor, K. K., ... Jones, M. O. (2014). Terrestrial hydrological controls on land surface phenology of African savannas and woodlands. Journal of Geophysical Research: Biogeosciences, 119(8), 1652-1669. doi: 10.1002/2013JG002572

Guswa, A. J. (2008). The influence of climate on root depth: A carbon cost- 
benefit analysis.

Water Resources Research, 44(2), 1-11.

doi: 10.1029/ 2007WR006384

Guswa, A. J. (2010). Effect of plant uptake strategy on the water-optimal root depth. Water Resources Research, 46(9), 1-5. doi: 10.1029/2010WR009122

Harris, I., Jones, P. D., Osborn, T. J., \& Lister, D. H. ～(2014). Updated highresolution grids of monthly climatic observations - the CRU TS3.10 Dataset. International Journal of Climatology, 34(3), 623-642. doi: 10.1002/joc.3711

Hengl, T., Mendes de Jesus, J., Heuvelink, G. B., Gonzalez, M. R., Kilibarda, M., Blagotić, A., .. Kempen, B. (2017). SoilGrids250m: Global gridded soil information based on machine learning. $\quad$ PLoS ONE, 12(2), 1-40. $\quad$ doi: 10.1371/journal.pone.0169748

Herrmann, S. M., \& Mohr, K. I. (2011). A continental-scale classification of rainfall seasonality regimes in Africa based on gridded precipitation and land surface temperature products. Journal of Applied Meteorology and Climatology, 50(12), 2504-2513. doi: 10.1175/JAMC-D-11-024.1

Howard, J., \& Merrifield, M. (2010). Mapping groundwater dependent ecosystems in California. PLoS ONE, 5(6). doi: 10.1371/journal.pone.0011249

Jacobson, P. J., \& Jacobson, K. M. (2013). Hydrologic controls of physical and ecological processes in Namib Desert ephemeral rivers: Implications for conservation and management. Journal of Arid Environments, 93, 80-93. doi: 10.1016/j.jaridenv.2012.01.010

Jin, X. M., Schaepman, M. E., Clevers, J. G., Su, Z. B., \& Hu, G. C. Groundwater depth and vegetation in the Ejina area, China. Arid Land Research and Management, 25 (2), 194-199. doi: 10.1080/15324982.2011.554953

Kleidon, A., \& Heimann, M. (1998). A method of determining rooting depth from a terrestrial biosphere model and its impacts on the global water and carbon cycle. Global Change Biology, 4(3), 275-286. doi: 10.1046/ j.1365-2486.1998.00152.x

Koirala, S., Jung, M., Reichstein, M., de Graaf, I. E., Camps-Valls, G., Ichii, K., .. Carvalhais, N. (2017). Global distribution of groundwater-vegetation spatial covariation. Geophysical Research Letters, 44(9), 4134-4142. $\quad$ doi: 10.1002/2017GL072885

Konings, A. G., \& Gentine, P. (2017). Global variations in ecosystem-scale isohydricity. Global Change Biology, 23(2), 891-905. doi: 10.1111/gcb.13389

Kuppel, S., Fan, Y., \& Jobbágy, E. G. (2017). Seasonal hydrologic buffer on continents: Patterns, drivers and ecological benefits. Advances in Water Resources, 102, 178-187. doi: 10.1016/j.advwatres.2017.01.004

Laio, F., D’Odorico, P., \& Ridolfi, L. (2006). An analytical model to relate the vertical root distribution to climate and soil properties. Geophysical Research Letters, 33(18), 1-5. doi: 10.1029/2006GL027331

Laio, F., Porporato, A., Fernandez-Illescas, C. P., \& Rodríguez-Iturbe, I. （2001). Plants in water-controlled ecosystems: Active role in hydrologic processes and response to water stress IV. Discussion of real cases. Advances in Water Resources, 24(7), 745-762. doi: 10.1016/S0309-1708(01)00007-0

Liu, Y., Kumar, M., Katul, G. G., \& Porporato, A. (2019). Reduced resilience as an early warning signal of forest mortality. Nature Climate Change, 9(11), 880885. doi: $10.1038 / \mathrm{s} 41558-019-0583-9$

Looney, C. E., Sullivan, B. W., Kolb, T. E., Kane, J. M., \& Hart, S. C. Pinyon pine (Pinus edulis) mortality and response to water addition across a three million year substrate age gradient in northern Arizona, USA. Plant and Soil, 357(1), 89-102. doi: 10.1007/s11104-012-1150-6

LSA-SAF. (2016). Algorithm Theoretical Basis Document for Vegetation parameters (VEGA) (Tech. Rep.). Retrieved from https://nextcloud.Isasvcs.ipma .pt/s/8AcY4xKqtAdLxY5

Ludwig, J. A., Wilcox, B. P., Breshears, D. D., Tongway, D. J., \& Imeson, A. C. 
(2005). Vegetation patches and runofferosion as interacting ecohydrological processes in semiarid landscapes. Ecology, 86(2), 288-297. doi: 10.1890/03-0569

Lv, J., Wang, X. S., Zhou, Y., Qian, K., Wan, L., Eamus, D., \& Tao, Z. Groundwater-dependent distribution of vegetation in Hailiutu River catchment, a semi-arid region in China. Ecohydrology, 6(1), 142-149. doi: $10.1002 /$ eco. 1254

Mansell, M. G., \& Hussey, S. W. (2005). An investigation of flows and losses within the alluvial sands of ephemeral rivers in Zimbabwe. Journal of Hydrology, 314(1-4), 192-203. doi: 10.1016/j.jhydrol.2005.03.015

Martens, B., Miralles, D. G., Lievens, H., Van Der Schalie, R., De Jeu, R. A., Fernández-Prieto, D., .. Verhoest, N. E. (2017). GLEAM v3: Satellitebased land evaporation and root-zone soil moisture. Geoscientific Model Development, 10(5), 1903-1925. doi: 10.5194/gmd-10-1903-2017

Martens, C., Hickler, T., Davis-Reddy, C., Engelbrecht, F., Higgins, S. I., von Maltitz, G. P., .. Scheiter, S. (2021). Large uncertainties in future biome changes in Africa call for flexible climate adaptation strategies. Global Change Biology, 27(2), 340-358. doi: 10.1111/gcb.15390

Martínez-de la Torre, A., Blyth, E. M., \& Robinson, E. L. $\quad$ (2019). Evaluation of drydown processes in global land surface and hydrological models using flux tower evapotranspiration. Water, 11. doi: 10.3390/w11020356

McCarthy, T. S. (2006). Groundwater in the wetlands of the Okavango Delta, Botswana, and its contribution to the structure and function of the ecosystem. Journal of Hydrology, 320(3-4), 264-282. doi: 10.1016/j.jhydrol.2005.07.045

McColl, K. A., Wang, W., Peng, B., Akbar, R., Short Gianotti, D. J., Lu, H., ... Entekhabi, D. (2017). Global characterization of surface soil moisture drydowns. Geophysical Research Letters, 44(8), 3682-3690. doi: 10.1002/2017GL072819

Merbold, L., Ardö, J., Arneth, A., Scholes, R. J., Nouvellon, Y., De Grandcourt, A., ... Kutsch, W. L. (2009). Precipitation as driver of carbon fluxes in 11 African ecosystems. Biogeosciences, 6(6), 1027-1041. doi: 10.5194/bg-6-1027-2009

Miralles, D. G., Holmes, T. R., De Jeu, R. A., Gash, J. H., Meesters, A. G., \& Dolman, A. J. (2011). Global land-surface evaporation estimated from satellitebased observations. Hydrology and Earth System Sciences, 15(2), 453-469. doi: 10.5194/hess-15-453-2011

Moré, J. J. (1978). The Levenberg-Marquardt algorithm: Implementation and Theory. In G. A. Watson (Ed.), Lecture notes in mathematics (pp. 105-116). Berlin: Springer-Verlag.

Müller, C., Waha, K., Bondeau, A., \& Heinke, J. (2014). Hotspots of climate change impacts in sub-Saharan Africa and implications for adaptation and development. Global Change Biology, 20(8), 2505-2517. doi: 10.1111/gcb.12586

Münch, Z., \& Conrad, J. (2007). Remote sensing and GIS based determination of groundwater dependent ecosystems in the Western Cape, South Africa. Hydrogeology Journal, 15(1), 19-28. doi: 10.1007/s10040-006-0125-1

Nash, E., \& Sutcliffe, V. (1970). River flow forecasting through conceptual models Part I - A discussion of principles. Journal of Hydrology, 10, 282-290. doi: 10 .1016/0022-1694(70)90255-6

Neale, C. M. (1997). Classification and mapping of riparian systems using airborne multispectral videography. Restoration Ecology, 5, 103-112. doi: 10.1111/j .1526-100X.1997.00103.x

Nelson, J. A., Pérez-Priego, O., Zhou, S., Poyatos, R., Zhang, Y., Blanken, P. D., ... Jung, M. (2020). Ecosystem transpiration and evaporation: Insights from three water flux partitioning methods across FLUXNET sites. Global Change Biology, 26(12), 6916-6930. doi: 10.1111/gcb.15314

Newman, B. D., Wilcox, B. P., Archer, S. R., Breshears, D. D., Dahm, C. N., Duffy, 
C. J., ... Vivoni, E. R. ments: A scientific vision. 10.1029/2005WR004141
(2006). Ecohydrology of water-limited environWater Resources Research, 42(6), 1-15. doi:

Nobre, A. D., Cuartas, L. A., Hodnett, M., Rennó, C. D., Rodrigues, G., Silveira, A., ... Saleska, S. (2011). Height Above the Nearest Drainage - a hydrologically relevant new terrain model. Journal of Hydrology, 404 (1-2), 13-29. doi: 10.1016/j.jhydrol.2011.03.051

Noy-Meir, I. (1973). Desert ecosystems: Environment and producers. $A n$ nual Review of Ecology and Systematics, 4(1), 25-51. doi: 10.1146/ annurev.es.04.110173.000325

Ouédraogo, D. Y., Hardy, O. J., Doucet, J. L., Janssens, S. B., Wieringa, J. J., Stoffelen, P., ... Fayolle, A. (2020). Latitudinal shift in the timing of flowering of tree species across tropical Africa: Insights from field observations and herbarium collections. Journal of Tropical Ecology. doi: $10.1017 /$ S0266467420000103

Palmer, P. I., Feng, L., Baker, D., Chevallier, F., Bösch, H., \& Somkuti, P. (2019). Net carbon emissions from African biosphere dominate pan-tropical atmospheric CO2 signal. Nature Communications, 10(1), 1-9. doi: 10.1038/s41467-019-11097-w

Peñuelas, J., Filella, I., Zhang, X., Llorens, L., Ogaya, R., Lloret, F., ... Terradas, J. (2004). Complex spatiotemporal phenological shifts as a response to rainfall changes. New Phytologist, 161(3), 837-846. doi: 10.1111/j.1469-8137.2004.01003.x

Porporato, A., Laio, F., Ridolfi, L., \& Rodríguez-Iturbe, I. (2001). Plants in watercontrolled ecosystems: active role in hydrologic processes and response to water stress: Iii. vegetation water stress. Advances in Water Resources, 24(7), 725-744. doi: 10.1016/S0309-1708(01)00006-9

Raduła, M. W., Szymura, T. H., \& Szymura, M. (2018). Topographic wetness index explains soil moisture better than bioindication with Ellenberg's indicator values. Ecological Indicators, 85(October 2017), 172-179. doi: 10.1016/j.ecolind.2017.10.011

Rodríguez-Iturbe, I., D’Odorico, P., Porporato, A., \& Ridolfi, L. (1999). On the spatial and temporal links between vegetation, climate, and soil moisture. Water Resources Research, 35(12), 3709-3722. doi: 10.1029/1999WR900255

Rousseeuw, P. J., \& Croux, C. (1993). Alternatives to the median absolute deviation. Journal of the American Statistical Association, 88(424), 1273-1283. doi: 10.1080/01621459.1993.10476408

Sala, O. E., Parton, W. J., Joyce, L. A., \& Lauenroth, W. K. (1988). Primary production of the central grassland region of the United States. Ecology, 69(1), 40-45. doi: 10.2307/1943158

Sankaran, M., Hanan, N. P., Scholes, R. J., Ratnam, J., Augustine, D. J., Cade, B. S., ... Zambatis, N. (2005). Determinants of woody cover in African savannas. Nature, 438(7069), 846-849. doi: 10.1038/nature04070

Sankaran, M., Ratnam, J., \& Hanan, N. (2008). Woody cover in African savannas: The role of resources, fire and herbivory. Global Ecology and Biogeography, 17(2), 236-245. doi: 10.1111/j.1466-8238.2007.00360.x

Scanlon, T. M., Caylor, K. K., Manfreda, S., Levin, S. A., \& Rodríguez-Iturbe, I. (2005). Dynamic response of grass cover to rainfall variability: Implications for the function and persistence of savanna ecosystems. Advances in Water Resources, 28 (3), 291-302. doi: 10.1016/j.advwatres.2004.10.014

Schenk, H. J. (2008). The shallowest possible water extraction profile: A null model for global root distributions. Vadose Zone Journal, 7(3), 1119. doi: 10.2136/ vzj2007.0119

Schenk, H. J., \& Jackson, R. B. (2002). Rooting depths, lateral root spreads and belowground aboveground allometries of plants in water limited ecosystems. 
Journal of Ecology, 90, 480-494. doi: 10.1046/j.1365-2745.2002.00682.x

Schmiedel, U., Jacke, V., Hachfeld, B., \& Oldeland, J. (2021). Response of Kalahari vegetation to seasonal climate and herbivory: Results of 15years of vegetation monitoring. Journal of Vegetation Science, 32(1), 1-13.

doi: $10.1111 /$ jvs. 12927

Simard, M., Pinto, N., Fisher, J. B., \& Baccini, A. (2011). Mapping forest canopy height globally with spaceborne lidar. Journal of Geophysical Research: Biogeosciences, 116 (4), 1-12. doi: 10.1029/2011JG001708

Singh, C., Wang-Erlandsson, L., Fetzer, I., Rockström, J., \& Van Der Ent, R.

(2020). Rootzone storage capacity reveals drought coping strategies along rainforest-savanna transitions. Environmental Research Letters, 15(12). doi: 10.1088/1748-9326/abc377

Tao, S., Guo, Q., Li, C., Wang, Z., \& Fang, J. (2016). Global patterns and determinants of forest canopy height. Ecology, 97(12), 3265-3270. doi: 10.1002/ecy .1580

Taylor, R. G., Todd, M. C., Kongola, L., Maurice, L., Nahozya, E., Sanga, H., \& Macdonald, A. M. (2013). Evidence of the dependence of groundwater resources on extreme rainfall in East Africa. $\quad$ Nature Climate Change, 3(4), 374-378. doi: 10.1038/nclimate1731

Teuling, A. J., Seneviratne, S. I., Williams, C., \& Troch, P. A. (2006). Observed timescales of evapotranspiration response to soil moisture. Geophysical Research Letters, 33(23), 0-4. doi: 10.1029/2006GL028178

Tian, F., Wigneron, J. P., Ciais, P., Chave, J., Ogée, J., Peñuelas, J., .. Fensholt, R. (2018). Coupling of ecosystem-scale plant water storage and leaf phenology observed by satellite. $\quad$ Nature Ecology and Evolution, 2(9), 1428-1435. doi: 10.1038/s41559-018-0630-3

Tian, S., Van Dijk, A. I., Tregoning, P., \& Renzullo, L. J. (2019). Forecasting dryland vegetation condition months in advance through satellite data assimilation. Nature Communications, 10(1), 1-7. doi: 10.1038/s41467-019-08403-x

Tootchi, A., Jost, A., \& Ducharne, A. (2019). Multi-source global wetland maps combining surface water imagery and groundwater constraints. Earth System Science Data, 892657, 189-220. doi: 10.5194/essd-11-189-2019

Tooth, S. (2000). Process, form and change in dryland rivers: A review of recent research. Earth Science Reviews, 51(1-4), 67-107. doi: 10.1016/S0012-8252(00) 00014-3

Trigo, I. F., Dacamara, C. C., Viterbo, P., Roujean, J. L., Olesen, F., Barroso, C., ... Arboleda, A. (2011). The satellite application facility for land surface analysis. International Journal of Remote Sensing, 32(10), 2725-2744. doi: 10.1080/01431161003743199

Tropical Rainfall Measuring Mission (TRMM). (2011). TRMM (TMPA) Rainfall Estimate L3 V7. Goddard Earth Sciences Data and Information Services Center (GES DISC). doi: 10.5067/TRMM/TMPA/3H/7

Valentini, R., Arneth, A., Bombelli, A., Castaldi, S., Cazzolla Gatti, R., Chevallier, F., ... Scholes, R. J. (2014). A full greenhouse gases budget of Africa: Synthesis, uncertainties, and vulnerabilities. Biogeosciences, 11(2), 381-407. doi: 10.5194/bg-11-381-2014

van Dijk, A. I., Peña-Arancibia, J. L., Wood, E. F., Sheffield, J., \& Beck, H. E. (2013). Global analysis of seasonal streamflow predictability using an ensemble prediction system and observations from 6192 small catchments worldwide. Water Resources Research, 49(5), 2729-2746. doi: 10.1002/wrcr.20251

van Wijk, M. T. (2011). Understanding plant rooting patterns in semi-arid systems: An integrated model analysis of climate, soil type and plant

biomass. Global Ecology and Biogeography, 20(2), 331-342. doi: 10.1111/ j.1466-8238.2010.00601.x

Wang, J., Song, C., Reager, J. T., Yao, F., Famiglietti, J. S., Sheng, Y., ... Wada, 
Y. (2018). Recent global decline in endorheic basin water storages. Nature

Geoscience, 11 (12), 926-932. doi: 10.1038/s41561-018-0265-7

Wang-Erlandsson, L., Bastiaanssen, W. G., Gao, H., Jägermeyr, J., Senay, G. B., Van Dijk, A. I., ... Savenije, H. H. (2016). Global root zone storage capacity from satellite-based evaporation. Hydrology and Earth System Sciences, 20(4), 1459-1481. doi: 10.5194/hess-20-1459-2016

Weber, U., Jung, M., Reichstein, M., Beer, C., Braakhekke, M., Lehsten, V., ... Ciais, P. (2009). The inter-annual variability of Africa's ecosystem productivity: a multi-model analysis. Biogeosciences, 6, 285-295. doi: 10.5194/bg-6-285-2009

Weerasinghe, I., Bastiaanssen, W., Mul, M., Jia, L., \& Van Griensven, A. (2020). Can we trust remote sensing evapotranspiration products over Africa. Hydrology and Earth System Sciences, 24 (3), 1565-1586. doi: 10.5194/hess-24-1565-2020

Wei, F., Wang, S., Fu, B., Wang, L., Liu, Y. Y., \& Li, Y. (2019). African dryland ecosystem changes controlled by soil water. Land Degradation and Development, 30 (13), 1564-1573. doi: 10.1002/ldr.3342

Wei, Z., Yoshimura, K., Wang, L., Miralles, D. G., Jasechko, S., \& Lee, X. Revisiting the contribution of transpiration to global terrestrial evapotranspiration. Geophysical Research Letters, 44(6), 2792-2801. 10.1002/2016GL072235

Wilcox, B. P., Le Maitre, D., Jobbagy, E., Wang, L., \& Breshears, D. D. (2017). Ecohydrology: Processes and implications for rangelands. In D. D. Briske (Ed.), Rangeland systems: Processes, management and challenges (pp. 85129). Springer International Publishing. doi: 10.1007/978-3-319-46709-2_3

Williams, C. A., \& Albertson, J. D. (2004). Soil moisture controls on canopy-scale water and carbon fluxes in an African savanna. Water Resources Research, 40(9), 1-14. doi: 10.1029/2004WR003208

Williams, C. A., Hanan, N. P., Neff, J. C., Scholes, R. J., Berry, J. A., Denning, A. S., \& Baker, D. F. (2007). Africa and the global carbon cycle. Carbon Balance and Management, 2(1). doi: 10.1186/1750-0680-2-3

Xu, X., Medvigy, D., Powers, J. S., Becknell, J. M., \& Guan, K. (2016). Diversity in plant hydraulic traits explains seasonal and inter-annual variations of vegetation dynamics in seasonally dry tropical forests. New Phytologist, 212(1), 80-95. doi: 10.1111/nph.14009

Yamazaki, D., Ikeshima, D., Sosa, J., Bates, P. D., Allen, G. H., \& Pavelsky, T. M. (2019). MERIT Hydro: A high-resolution global hydrography map based on latest topography dataset. Water Resources Research, 55(6), 5053-5073. doi: 10.1029/2019WR024873

Yan, D., Zhang, X., Yu, Y., \& Guo, W. (2016). A comparison of tropical rainforest phenology retrieved from geostationary (SEVIRI) and polar-orbiting (MODIS) sensors across the Congo Basin. IEEE Transactions on Geoscience and Remote Sensing, 54 (8), 4867-4881. doi: 10.1109/TGRS.2016.2552462

Yan, D., Zhang, X., Yu, Y., \& Guo, W. (2017). Characterizing land cover impacts on the responses of land surface phenology to the rainy season in the Congo Basin. Remote Sensing, 9(5). doi: 10.3390/rs9050461

Yang, Y., Donohue, R. J., \& McVicar, T. R. (2016). Global estimation of effective plant rooting depth: Implications for hydrological modeling. Water Resources Research, 52, 8260-8276. doi: 10.1111/j.1752-1688.1969.tb04897.x

Zeng, L., Wardlow, B. D., Xiang, D., Hu, S., \& Li, D. (2020). A review of vegetation phenological metrics extraction using time-series, multispectral satellite data. Remote Sensing of Environment, 237, 111511. doi: 10.1016/j.rse.2019.111511

Zhang, J., Felzer, B. S., \& Troy, T. J. (2016). Extreme precipitation drives groundwater recharge: the Northern High Plains Aquifer, central United States, 19502010. Hydrological Processes, 30(14), 2533-2545. doi: 10.1002/hyp.10809 
Zhang, W., Brandt, M., Penuelas, J., Guichard, F., Tong, X., Tian, F., \& Fensholt, R. (2019). Ecosystem structural changes controlled by altered rainfall climatology in tropical savannas. $\quad$ Nature Communications, 10(1). doi: 10.1038/s41467-019-08602-6

Zimba, H., Kawawa, B., Chabala, A., Phiri, W., Selsam, P., Meinhardt, M., \& Nyambe, I. (2018). Assessment of trends in inundation extent in the Barotse Floodplain, upper Zambezi River Basin: A remote sensing-based approach. Journal of Hydrology: Regional Studies, 15(January), 149-170. doi: 10.1016/j.ejrh.2018.01.002 